\title{
Innovativeness, Firm Performance and Managers' Educational Level: A Study of Selected SMEs in Yobe State, Nigeria
}

Sani Mohammed, Noraini Abu Talib and Umar Haiyat Abdul Kohar

To Link this Article: http://dx.doi.org/10.6007/IJARBSS/v10-i12/8104

DOI:10.6007/IJARBSS/v10-i12/8104

Received: 11 October 2020, Revised: 02 November 2020, Accepted: 24 November 2020

Published Online: 08 December 2020

In-Text Citation: (Mohammed et al., 2020)

To Cite this Article: Mohammed, S., Talib, N. A., \& Kohar, U. H. A. (2020). Innovativeness, Firm Performance and Managers' Educational Level: A Study of Selected SMEs in Yobe State, Nigeria. International Journal of Academic Research in Business and Social Sciences, 10(12), 201-223.

Copyright: @ 2020 The Author(s)

Published by Human Resource Management Academic Research Society (www.hrmars.com)

This article is published under the Creative Commons Attribution (CC BY 4.0) license. Anyone may reproduce, distribute, translate and create derivative works of this article (for both commercial and non-commercial purposes), subject to full attribution to the original publication and authors. The full terms of this license may be seen

at: http://creativecommons.org/licences/by/4.0/legalcode

Vol. 10, No. 12, 2020, Pg. 210 - 223

Full Terms \& Conditions of access and use can be found at http://hrmars.com/index.php/pages/detail/publication-ethics 


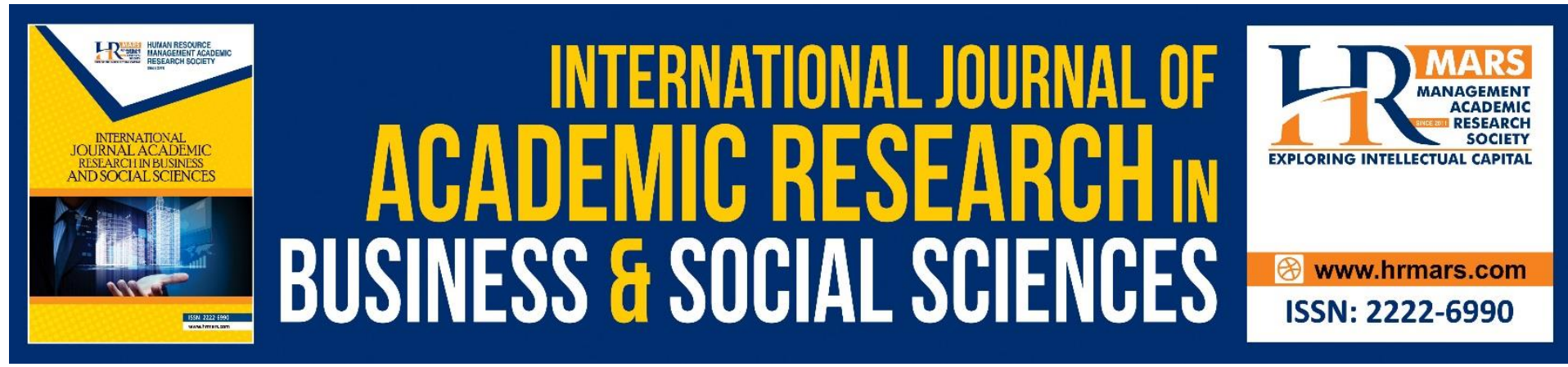

\title{
Innovativeness, Firm Performance and Managers' Educational Level: A Study of Selected SMEs in Yobe State, Nigeria
}

\author{
Sani Mohammed, Noraini Abu Talib and Umar Haiyat Abdul \\ Kohar \\ Department of Business Administration, Azman Hashim International Business School, \\ Universiti Teknologi Malaysia, Johor, Malaysia \\ Email:msani@graduate.utm.my,m-aini@utm.my,umarhaiyat@utm.my
}

\begin{abstract}
The objectives of the study are two folds: to investigates the relationship between innovativeness and firm performance, and to moderate such relationship with educational level of managers. In attempt to justify the effect of innovativeness on SMEs performance, structured questionnaire in a 5-point Likert Scale was applied in collecting data. Total of 259 respondents were drawn as sample. The data were analyzed using SPSS 25 version for descriptive statistics, normality and common method variance. Analyses of measurement model for internal consistency, discriminant validity, and composite reliability were conducted in PLS 3. Hypotheses of the study were confirmed by applying (SEM) technique in PLS-SEM. The current study moreover, indicates that managers' educational level moderates' relationship between innovativeness and firm performance. The study declares that educational level of managers affect relationship between innovativeness and performance of SMEs in Nigeria. Thus, the findings could be used by government to develop policy decision on loan advances to be based on one's level of education. Prior to this study, there has been no study that tries to blend managers' own level of education with innovativeness and firm performance with a view to assessing its moderating effect, this study fills this gap.
\end{abstract}

Keywords: Firm Performance, Innovativeness, Educational Level, SMEs

\section{Introduction}

The crucial function SMEs uphold in every economy is not disputable (Wang et al., 2015). SMEs constitute over $90 \%$ of entire firms, with $70 \%$ job creation rate and accounted for $60 \%$ GDP in Pakistan (Jawad, 2015). Ghana's case for instance, has greater than $90 \%$ of companies running SMEs and their contribution to GDP stand at $70 \%$; with over $80 \%$ job creation rate (Abor, \& Quartey, 2010). SMEs were reported in the Global Alliance 2013 reported that the percentage of SMEs compared to entire business enterprises surpasses $95 \%$ and accounted for over $50 \%$ jobs available in developed countries e.g. Germany, U.S, and UK. In Africa, SMEs contributed about $70 \%$ of GDP. The SMEs constitutes about $92 \%$ of total businesses in Ghana, South Africa and Nigeria with over $70 \%$ manufacturing firms existing as SMEs (Gatt, 2012; Darwish et al., 2018). 
Unfortunately, slow SMEs performance in Nigeria degenerated most often in their collapse. One out of every five businesses doesn't survive beyond 5years (Kaigama, 2018). For this reason, stakeholders have put SMEs under close watch in order to improve their performance and tap from the welfare of the SMEs existence to benefit government, owners, and the community in general (Kaigama, 2018). (Cooper, Woo \& Dunkelberg, 1988) Emphases that business that lived up to 5 years are said to be successful. Firms do not get to their maturity (Byrne \& Shepherd, 2015). Only one of three newly established firms survive to 2 years in their operation with $90 \%$ of them surviving not growing their number of employees (Cook \& Alex, 2016). Giving the above preamble, the need to improve firm performance is of paramount importance; hence, the idea to harness innovativeness and firm performance.

\section{Objectives of the Study}

The main objective of the study is to examine the relationship of innovativeness and firm performance with a view to moderating it with educational level of managers of the firms. The specific objectives of the study are:

i. To examine the direct relationship between innovativeness and SMEs performance in Nigeria.

ii. To find out if educational level of firm managers can moderate the relationship between innovativeness and firm performance.

\section{Research Question}

In order to achieve the objective of the study, the following research questions were coined to ease the research process:

i. Does direct relationship exist between innovativeness and SMEs performance in Nigeria?

ii. Can Managers' own level of education moderate the relationship between innovativeness and SMEs performance in Nigeria?

\section{Review of Related Literature}

Innovativeness has been discussed widely as one of the dimensions of entrepreneurial orientation (EO). According to (Miller, 1983) and other researchers that followed such as (Covin \& Slevin, 1989), EO has three dimensions. These are innovativeness, proactiveness and risk taking. This is want come to be known as unidimensional approach. Researchers like (Lumpkin \& Dess, 1996) believe that EO should have five dimensions these include an additional two more dimension to the early unidimensional constructs. These additions are competitive aggressiveness and autonomy. This is now known as multidimensional approach. In either case, innovativeness is the heart of the discourse. The idea of innovativeness is to enhance firm performance through making major positive changes to equipment and processes of production and administration with a view to boosting productivity and profitability. However, innovativeness is not easy to achieve by SMEs because it is cost intensive, particularly the technological innovativeness. Management innovativeness is not cost intensive but does not boost productivity (Benton, 2017). This could be because of the law of diminishing return to scale that sets in and destabilise the process. It is noteworthy that the management of human resource translates to variable cost, thus any increase in spending on human resource without commensurate increase in the fixed factor that is the 
'technological aspect of innovativeness' a smaller and smaller addition to the total output will be the resultant effect.

Therefore, the take away here is that, technologic innovativeness is not easy to be achieved by the SMEs because of its capital intensity. Meanwhile, the management innovativeness which the SMEs can afford to does not results in increased production due to the law of diminishing return to scale.

\section{Innovativeness vs. SMEs Performance}

Largely defined, innovation refers to forming new produces; i.e. improving on existing commodity put in the marketed; and introducing entirely new goods to target markets (Dale Cake Radical Innovation Launch Success: A Market, Entrepreneurial, Learning Orientation and Dynamic Capabilities and Integration Process Model Dale Cake Doctor of Business Administration (D . B . A .) May 2018 Jacksonville University Davis Colleg, 2018). Innovativeness covers ways of creating products which is novel or a kind of important improvement on manufacturing procedure, distribution or goods dispersal methods; and organisational and administrative modifications which ensure forming or changing the structural composition and samples, management of personnel and re-composing product nature (Trott, 2010). Therefore, the business's innovative capability is explained through their ability to deploy the know-hows, of their employees (Kogut \& Zander, 1996). Scholars are certain that innovation of goods and the operational process are significant reducing cost of operational. Hence, rising the probabilities of initiating new markets and increase the revenues accruing to the firm (Prajogo, 2015; Lee \& Wenyi Chu, 2017; Wadho \& Chaudhry, 2018; Lii \& Kuo, 2016).

(Drucker, 2009) believes innovation is shielding the heart of entrepreneurship; stating further that organization stands to gain more with changing marketplace conditions through innovation and maintaining such innovative activities. After achieving that, the degree of inventiveness of a firm may be holistically strengthened and sincerely matched with all existing firm's structure; hence, the situation could be to boost greater business performance. Procedural concept advocates that firms may accomplish greater performance by modifying procedure by which "average outcome" is formed e.g. through evolving novel services and products (Trieu, 2017). At this level, the business might be ready to achieve competitive advantage by way of creating novel products, that are offered to a particular target market (Hornsby et al., 2002). SMEs need promptly present intensify their essential innovations strategies in order to withstand horrible business environment characterised by deep competition, (Bozic \& Dimovski, 2019). With the above discussions, the below hypothesis is formulated to guide the study.

$\mathrm{Ho}_{1}$ There is significant direct relationship between innovativeness and SMES performance in Nigeria.

\section{Educational level and SMEs Performance}

Education is valuable to entrepreneurs and recognizing this, researchers became interested in educating 'to-be-entrepreneurs' with knowledge that can suits the entrepreneurs purpose known as "entrepreneurship education". Entrepreneurship education "provides good understanding of the ways learners across culture and gender involve in acquiring practical viable business knowledge through multi-dimensional logic of discharging duty, autonomous 
conducts of reasoning, couple with the ability to exhibits personal other than peoples' desires" (Genty et al., 2015; Mueller, and Anderson, 2014). Studies suggested relationship exist between the performance firms and manager's own education (van der Sluis et al., 2007). Managers' own educational level is important booster of firms' progress and a crucial factor in improving performance (Gunasekaran et al., 2011; Karadag, 2017).

Business managers who got trained and educated influences firm performance and business achievements as it assists the procedure through which managers build knowledge, confidence, psychology and skills which are key to developing absorptive capacity. Educated businessmen or managers are creative, innovative and scramble always for distinctive issues that aids satisfactions of want (Ahrari et al., 2018; Chowdhury et al., 2013). Business managers need decision-making skills, technical skills etc. which are required for modelling goods or services for the business, which are desirable for accomplishing specific undertakings in the organization (Idris, and Kabiru, 2014; Salome, Osita, \& Marcel, 2012; Genty et al., 2015). Additionally, education supports development of high self-efficacy in business managers, to the extent that it become extreme and therefore harmful to the performance business (Didonet et al., 2012; Cooper \& \& Schindler, 1998).

Vallabh \& Mhlanga, (2015) emphasised on how educating and training Small and Medium Tourism Enterprises (SMTEs) managers aids them with the competencies to solving numerous management hitches that are challenging to the firms; underscoring that educating about practices of business, the firms gain some benefits tactically, operationally and strategically. Several Studies suggest that level of education of entrepreneurs constitutes business success factors of SMEs activities; and help boost performance as it ensure management of business environment intricacies and sustain development of the business (Rojas Hernandez, 2018; Boling et al., 2016) believed that characteristics of CEO's impact on firm's performance and EO connection positively. At this rate, the hypothesis below is framed to examine the degree to which managers' own educational level could moderate relationship between EO-firm performances.

$\mathrm{Ho}_{6}$ : The positive relationship between innovativeness and performance of SMEs in

Northeast of Nigeria would be stronger for owner/managers with higher educational level

\section{Conceptual Framework}

Figure 1 below is the framework of the current study showing he relationship between the Innovativeness and the firm performance linked with a horizontal arrow while the moderating relationship is linked with vertical arrow. The study hypothesised that if educational level of managers is high, the relationship between the innovativeness and firm performance will be stronger. People who possess education particularly higher education are expected to possess high problem-solving ability, creative and to be more ingenious and resourceful than people with low or not educated. 


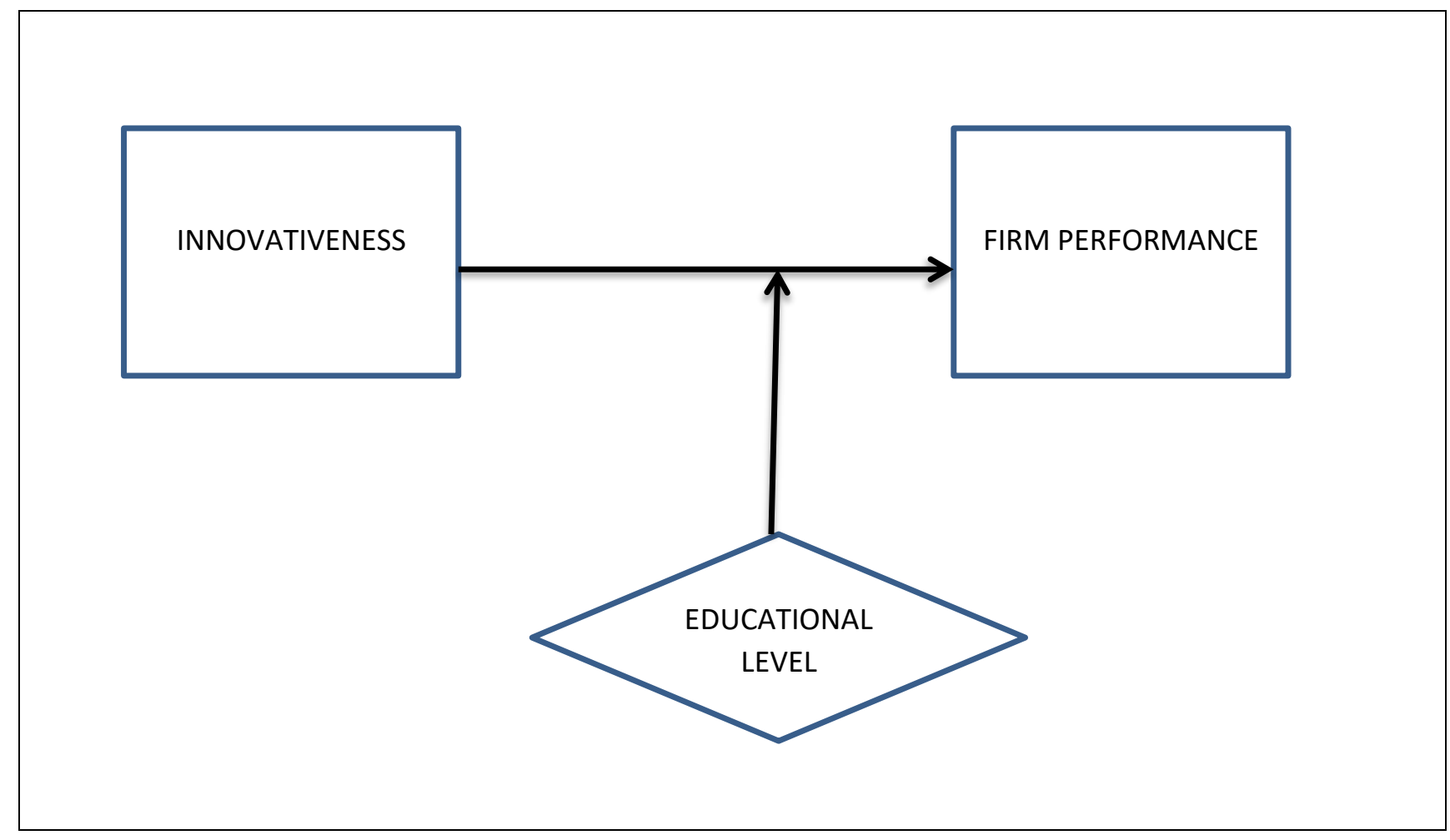

Figure 1. Conceptual Frame

\section{Research Methodology}

Research methodology refers to a technique of solving problem and reaching to novel information about particular issue (Shah et al., 2018). Everything that contributes to the goal's achievement is part of the research methodology. Find below a detailed explanation on the methodology adopted for this study.

The target population of this research is managers of firm in the manufacturing operating in Yobe State, Nigeria. In order to smoothly achieve the objectives of the study, structured questionnaire was applied to collect the data. This method was selected for its cost effectiveness (both money and time wise) as compared to mail or interviews (Bell \& Bryman, 2007). The second reason is because of the caliber and responsibilities of the respondents who are managers of firms extremely busy all the times; and might not have ample time to grant interviews. In this way, questionnaires should be the appropriate methods for collecting the data as they can fill in the form at their leisure times.

In all, 365 copies of questionnaires were delivered directly to managers of firms operating manufacturing sector in Yobe State. The firms studied were selected randomly from SMEDAN record of SMEs in Nigeria. 287 questionnaires were returned; but of this, only 259 of the questionnaires were filled completely by the managers and hence, the number of questionnaires used for analysis, which represent $73 \%$ per cent. In a quantitative study, minimum of 100 respondents are enough to come up with adequate data and reliable analysis (Hair et al., 2010). Hence, the respondents are adequate for this study. Five-point Likert scales types of questionnaire with ' 1 strongly disagree and 5 strongly agree' was used to collect primary data. The questionnaire contains closed questions. The questionnaire consisted of three sections. Section ' $A$ ' deals with the respondents' demographic information. Other sections include Section ' $B$ ' which contains questions on the independent variable that is 
innovativeness and section ' $C$ ' which contains questions on the dependent variable i.e. firm performance.

\section{Descriptive Data}

Table 1 above depicts the respondents' information regarding gender, age, marital statuses etc. 200 of the respondents are male and this is $77 \%$. Female constitute 51 and $24 \%$. With regards to educational level, 105 of them are at the high level of education and that is $41 \%$ while lower level of education has 154 that are $59 \%$. With regard to Business age, there are 211 businesses and that is 77\% of all the businesses considered for this study in the category of $0-5$ years. 40 of them are in the category of $6-10$ years i.e. $15 \%$ with only 8 i.e. $3 \%$ of the businesses in the category of 11 years and above. The number of employees shows that 229 of the firms employs between $10-49$ and that is $88 \%$ while 30 of them employ i.e. $12 \%$ between $50-199$. See table 1 below

\section{Table 1 Respondent information}

\begin{tabular}{|l|cc|}
\hline Variable & Frequency & Percentage \\
\hline Gender: & 200 & 77 \\
Male & 51 & 24 \\
Female & & \\
Educational Level: & 105 & 41 \\
Higher level of Education & 154 & 59 \\
Lower level of Education & & \\
& 211 & 82 \\
Business Age: & 40 & 15 \\
0 until 5years & 8 & 3 \\
6-10years & & \\
11 years and above & & 77 \\
Marital Status: & 201 & 34 \\
Married & 58 & \\
Single & & 88 \\
Number of Employees: & 229 & 12 \\
$10-49$ & 30 & \\
$50-199$ & & \\
\end{tabular}

\section{Analysis and Discussions}

The data collected through the administered questionnaire were analyzed using SPSS and PLS-SEM application. In the firstly place, a pilot test was conducted to examine reliability and validity of the adopted instrument. Techniques of statistics applied to attain the study objectives are: value of Cronbach's Alpha test, composite reliability (CR), average variance expected ( $\mathrm{AVE}$ ), all in Structural equation modeling (SEM) technique. See table 2 below. 
Table 2 Measurement model for Innovativeness

\begin{tabular}{|c|c|c|c|c|c|c|}
\hline Construct & Item & Factor Loading & CR & AVE & Alpha & rho_A \\
\hline Innovativeness & QINN1 & 0.782 & $\begin{array}{l}0.89 \\
5\end{array}$ & 0.681 & 0.843 & 0.848 \\
\hline & QINN2 & 0.848 & & & & \\
\hline & QINN3 & 0.855 & & & & \\
\hline & QINN4 & 0.812 & & & & \\
\hline
\end{tabular}

The result of the measurement model analysis indicates all items have loaded greater 0.78 . Also, the latent construct has composite reliability value is greater than 0.7 , and the AVE excess 0.5 threshold. It equally has the Cronbach's alpha of 0.843 which is greater than the threshold of 0.7. This suggests that the items are reliable and valid for SEM analysis to be performed.

Table 3 Discriminant Validity

\begin{tabular}{|l|c|c|}
\hline Construct & INN & SMEP \\
\hline Innovativeness & $\mathbf{0 . 8 2 5}$ & \\
\hline Business Performance & 0.518 & $\mathbf{0 . 7 8 3}$ \\
\hline
\end{tabular}

In table 3 above, the two constructs are measure for discriminant validity. The result shows no issues with discriminant validity as the correlation coefficient for innovativeness $(0.825)$ is higher compared to the correlation it has with the Business performance (0.518).

Table 4 Structural estimates (Direct Effect/Relationship)

\begin{tabular}{|l|l|l|l|c|c|}
\hline No. & \multicolumn{1}{|c|}{ Path } & Beta $(\boldsymbol{\beta})$ & T-Value & $\begin{array}{c}\mathbf{p}- \\
\text { value }\end{array}$ & Decision \\
\hline $\mathbf{H}_{2 \mathbf{a}}$ & $\begin{array}{l}\text { Innovativeness -> Business } \\
\text { Performance }\end{array}$ & -0.019 & 0.285 & 0.775 & $\begin{array}{c}\text { Not } \\
\text { Supported }\end{array}$ \\
\hline
\end{tabular}

Innovation has no significant effect on firm results in table $4(\beta=-0.019, t$ value 0.285 and $p$ value greater than 0.0775$)$ from table 4 above. Therefore, the outcome indicates that the relationship is not important, and the hypothesis suggested was not endorsed. That is, innovativeness doesn't have a big effect on business results. Hence, the first hypothesis is hereby rejected.

\section{Moderating Effect}

H2: The high the Education Level of owner/managers of SMEs in Yobe state, the stronger will be the relationship between Innovativeness and performance of Business.

In line with the structural model, the outcome obtained from Figure 2 was used (Hair et al., 2017). The corresponding t-values, path coefficients or beta ( $\beta$ ), P-values are stated to make a judgement on the hypothesis. At least at the significance level of 0.05 , the $\beta$ value must account for a certain effect within the model and the t value should be greater than 1.96 (Hair et al., 2013). 


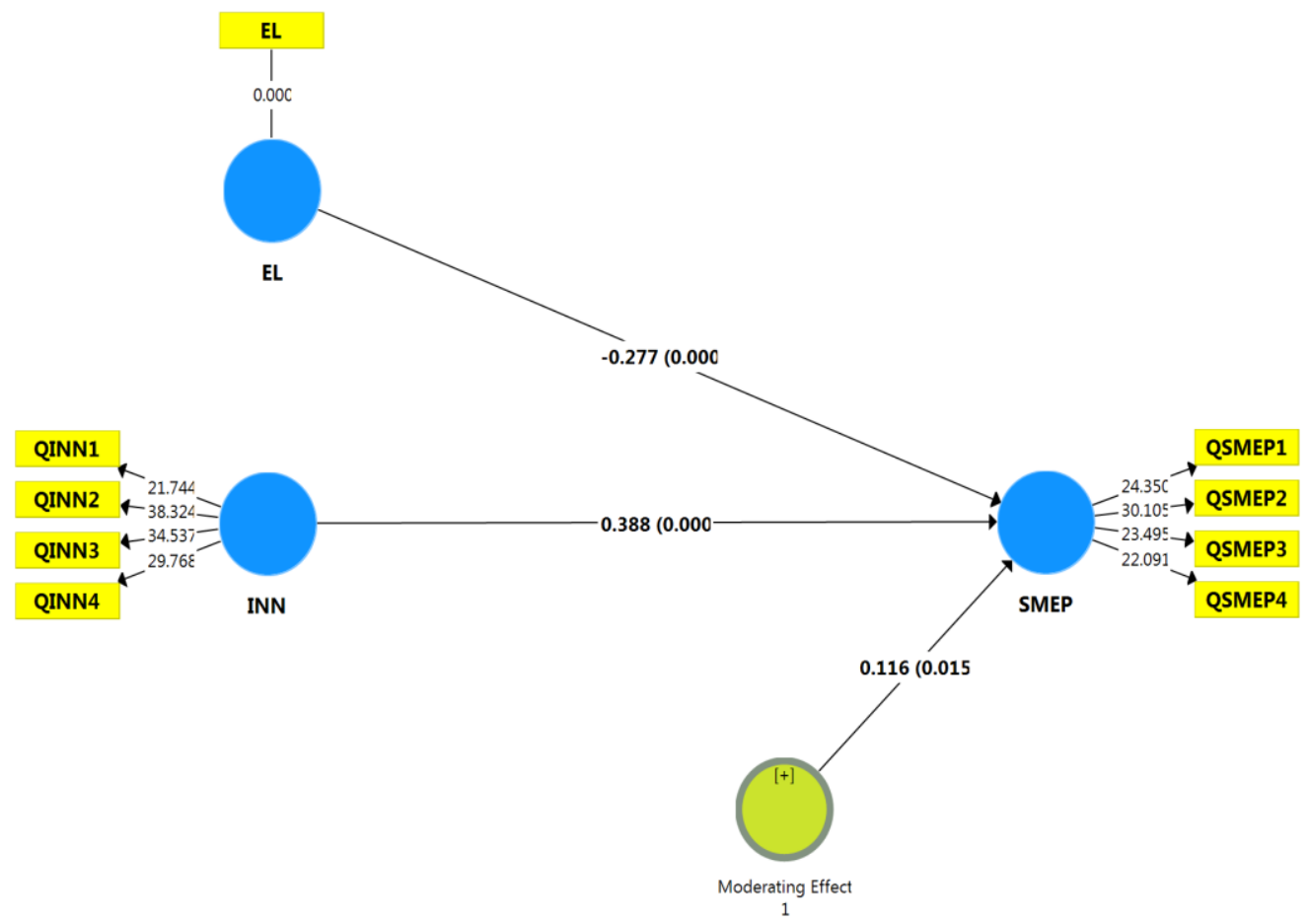

Figure 02 Moderating Effect of EL (INN -> SMEP)

Table 5. Moderating effect

\begin{tabular}{|l|l|l|l|}
\hline Path & Beta $(\boldsymbol{\beta})$ & T-Values & P-Values \\
\hline EL -> SMEP & -0.277 & 5.765 & 0.000 \\
\hline INN -> SMEP & 0.388 & 7.029 & 0.000 \\
\hline Moderating Effect 1 -> SMEP & 0.116 & 2.433 & 0.015 \\
\hline
\end{tabular}

As presented in Figure 2 and Table 5 educational level have significant moderating effect on the relationship between innovativeness and business performance $(\beta=0.116, t=$ $2.433 ; p<0.05)$. Similarly, this moderating effect means that, with the highest level of education the relationship between innovativeness and business performance will be affected. Thus, the education level helps to strengthen the effect of innovativeness on business performance

\section{Discussions Finding}

One of the fundamental aims of this thesis is to analyse the relationship between innovation and the success of SMEs. The result shows that the innovativeness and efficiency of SMEs operating in the study area are not related. That is to say that innovation by SMEs in the area does not accounts for higher or improved performance according to the findings. This result is not consistent with some studies which have found that the success of SMEs is linked to innovation. The ability of companies to be creative in terms of new technologies, new processes and new business discovery and penetration are the cornerstone for SMEs to achieve superior performance; this is accomplished by improving their competitive advantage and remaining ahead of their market rivals (Inegbedion, 2019; Monteiro et al., 2019). There are, however, cases where creativity is not substantially positive in relation to the success of 
SMEs. This illustrates the need for greater emphasis on the structures being studied. In another development, (Atalay., 2013) states that there was no significant relationship between non-technologically driven performance and innovation of SMEs, but they found a significant positive relationship between company performance and technologically focused innovations. This current study is congruent with the study by (Benton, 2017).

Unfortunately, technologically focused developments are capital intensive and not every small and medium-sized company can afford them, particularly those in the field of research. No important positive relationship between SMEs and innovations in testing hypotheses, i.e. innovativeness, was also found in the current research. Technologicallyoriented developments require a significant amount of institutional capital, but not every organisation can afford it. The results of the current study indicate that it is difficult for small and medium-sized enterprises in Northeast Nigeria to transfer their enterprises to higher performance through innovation. This is a logical consequence of what these corporations have in terms of financial value and other properties. In other words, businesses are unable to afford the technical type of innovation, which implies that they rely only on nontechnological innovation that does not guarantee superior output (Atalay, 2013). Similar study by (Benton, 2017) found no direct impact of management innovation on company performance. In another development, results of research by (Hernandez-Linares et al, 2019) showed innovation has a negative relationship between company performance. (Chin et al., 2016) Found a negative relationship between EO and company performance at the time of what they did. These findings reinforced the findings (Atalay, 2013) and both studies accepted and endorsed the recent study findings which showed that the type of innovation adopted by SMEs in the Northeast of Nigeria does not significantly promote improved business efficiency.

It is interesting to noted that while the direct relationship between the major construct of the study i.e. innovativeness and firm performance showed negative, the moderating effect turned out to be positive. From table 5 , it is noticeable that the result generated beta values of $0.116, t$-value of 2.433 and $p$-value of 0.015 ; and all these values have reached their thresholds. Hence, this signifies that the moderating factor i.e. educational level of managers can play a significant role in boosting firm performance. It therefore implies that managers with higher educational level are more likely to be innovative and to foster firm performance because of their level of education. This is consistence with study by Gunasekaran et al., (2011) and Karadag, (2017) who assert that managers' own educational level is vital driver of firm progress and main cause of performance.

\section{Conclusion}

By way of conclusion, the study has found a significant influence of educational level of managers on the relationship between the innovativeness and SMEs performance. While the direct relationship indicated a non-significant influence, the moderation effect as seen in table 5 indicate a tremendous influence and has change the relationship to a significant positive relationship. So, this implies that with high educational level, a stronger relationship is created between the innovativeness and firm performance. It is particularly true because highly educated individuals are expected to have strong problem-solving ability, active creative urge and more prone to developing on their intuitive drive. These characteristics are good promoters of innovativeness. 


\section{Recommendation}

The following recommendations are postulated for the benefit of all stakeholders in affairs of SMEs' progress in Nigerian context. Firstly, managers should make sure they embody innovation into operations of their business, but where the manager is not highly educated particularly with business knowledge, the services of consultants may be essential in order to formulate the most befitting form of innovativeness that could work out well for them. By so doing, the much-needed innovation can be generated because they possess high creative ability, problem solving ability and so innovations can be achieved with relative ease. Secondly, government should as a matter of exigency form a guideline for accessing loanable fund involving huge amount to be granted only to businesses whose managers possess higher education as this will benefit the economy directly since they can mastermind their operations to boost SMEs performance. Thirdly, the government need to provide free of charge services of those of consultant who might be paid by the government to provide the needed consultancy services in order to boost innovation. If all these are done, there will be drastic change in the negative innovation saga which bedevils the operations of SMEs over the year. Hence, SMEs will start booming, huge employment will be created, investors' confidence can be restored, standard of living will be uplifted, and above able, the government may have created additional revenue avenue.

\section{Future Research Directions}

The current study tries to see the influence of innovativeness on SMEs performance particularly in Nigerian businesses. Additionally, the size of sample seems rather small and from only one region. It is worthwhile for scholars, to authenticate the findings applying bigger samples and lager assortment of respondents cutting across other regions of the Nigeria as well. Further research, can be established in link between innovativeness and performance of firms by applying new and suitable moderator and/or mediators variables to get clear and comprehensive view of the relations between innovativeness and SMEs performance. Also, further study may choose to apply other nonparametric techniques of analysis such as Kruskal Wallis test, Man-Whitney's test etc.

\section{Declaration}

The study sourced for the data using enumerators who were trained on how to go about administering the questionnaire. There are available data provided for the research. Additionally, there is no competing interest what so ever amongst the co-authors. On the issue of funding, there is no anybody that sponsored this research. The researchers funded the research themselves. The second author initiated the topic and gave objectives of the study, the first author made introduction and analysis of the data while the third author interpreted and discussed findings.

\section{Reference}

Abor, J., \& Quartey, P. (2010). Issues of SMEs development in Ghana and South Africa. JInternational Ournal of Finance and Economics, 2(8), 1 - 14.

Ahrari, S., Krauss, S. E., Ariffin, Z., \& Meng, L. K. (2018). A Network-Based Approach for Emerging Rural Social Entrepreneurship. International Journal of Academic Research in Business and Social Sciences, 8(9), 493-513. https://doi.org/10.6007/IJARBSS/v8i9/4608

Atalay. (2013). The Relationship between Innovation and Firm Performance: An emperical 
evidence frm Turkish Automotive Supplier Industry. Proceedia Social and Behaviour Science, 75, 226-235.

Bell, E., \& Bryman, A. (2007). The Ethics of Management Research : An Exploratory Content Analysis. 18, 63-77. https://doi.org/10.1111/j.1467-8551.2006.00487.x

Benton, R. M. C. (2017). Management innovation and firm performance : the mediating effects of tacit and explicit knowledge. Knowledge Management Research \& Practice. https://doi.org/10.1057/s41275-017-0058-6

Boling, J. R., Pieper, T. M., \& Covin, J. G. (2016). CEO Tenure and Entrepreneurial Orientation Within Family and Nonfamily Firms. Entrepreneurship: Theory and Practice, 40(4), 891913. https://doi.org/10.1111/etap.12150

Bozic, K., \& Dimovski, V. (2019). Business intelligence and analytics for value creation: The role of absorptive capacity. International Journal of Information Management, 46(November 2018), 93-103. https://doi.org/10.1016/j.ijinfomgt.2018.11.020

Byrne, O., \& Shepherd, D. A. (2015). Different Strokes for Different Folks: Entrepreneurial Narratives of Emotion, Cognition, and Making Sense of Business Failure.

Entrepreneurship: Theory and Practice, 39(2), 375-405. https://doi.org/10.1111/etap.12046

Chin, T., Tsai, S., Fang, K., Zhu, W., Yang, D., \& Tachia, C., Sang-Bing, T., Kai, F., Wenzhong, Z., Dongjin, Y., Ren-huai, L., et al. (2016). EO-Performance relationships in Reverse Internationalization by Chinese Global Startup OEMs: Social Networks and Strategic Flexibility. PLoS One., 11((9)), 120. https://doi.org/10.1371/journal.pone.0162175

Chowdhury, M. S., Islam, R., \& Alam, Z. (2013). Constraints to the Development of Small and Medium Sized Enterprises in Bangladesh: An Empirical Investigation. Australian Journal of Basic and Applied Sciences, 7(8), 690-696.

Cook, E. O., \& Alex, P. (2016). Growth Entrepreneurship in Developing Countries / infoDev. http://www.infodev.org/growth-entrepreneurship

Cooper, A. C., Woo, C. Y., \& Dunkelberg, W. C. (1988). Entrepreneurs' perceived chances for success. Journal of Business Venturing, 3((2)), 97-108.

Cooper, D. R., \& \& Schindler, P. S. (1998). Business Research Methods. McGraw-Hill,.

Covin, J. G., \& Slevin, P. D. (1989). Strategic Management of Small Firms in Hostile and Benign Environments Author ( $s$ ): Jeffrey G . Covin and Dennis P. Slevin Published by : Wiley Stable URL : https://www.jstor.org/stable/2486395 REFERENCES Linked references are available on JSTOR for thi. Strategic Management Journa, 10(1), 75-87.

Darwish, S., Abdo, H., \& AlShuwaiee, W. M. (2018). Opportunities, challenges and risks of transition into renewable energy: the case of the Arab Gulf Cooperation Council. International Energy Journal, 18(4).

Dale Cake Radical Innovation Launch Success : A Market, Entrepreneurial, Learning Orientation and Dynamic Capabilities and Integration Process Model Dale Cake Doctor of Business Administration ( D . B . A .) May 2018 Jacksonville University Davis Colleg. (2018). May.

Didonet, S., Simmons, G., Díaz-Villavicencio, G., \& Palmer, M. (2012). The relationship between small business market orientation and environmental uncertainty. Marketing Intelligence and Planning, 30(7), 757-779. https://doi.org/10.1108/02634501211273841

Drucker, P. F. (2009). Innovation And Entrepreneurship : Practice And Principles. . ix, 277. Gatt, L. (2012). SMEs in Africa: Growth despite constraints. Retrieved@www.consultancyafrica.com. 
Genty, K., Idris, K., Wahizat, N., Wahat, A., \& Kadir, S. A. (2015). HC-Theo-Exp\&Edu-REFR-DVREAD-Demographic Factors and Entrepreneurial Success : A Conceptual Review. International Journal of Management Sciences, 6(8), 366-374.

Gunasekaran, A., Rai, B. K., \& Griffin, M. (2011). Resilience and competitiveness of small and medium size enterprises: An empirical research. International Journal of Production Research, 49(18), 5489-5509. https://doi.org/10.1080/00207543.2011.563831

Hair, J. F., Black, J. W., Babin, B. J., \& Anderson, E. R. (2010). Multivariate data analysis (Seventh Ed). Pearson Education Limited.

Hair, J. F., Ringle, C. M., \& Sarstedt, M. (2013). Partial Least Squares Structural Equation Modeling: Rigorous Applications, Better Results and Higher Acceptance. Long Range Planning, 46(1-2), 1-12. https://doi.org/10.1016/j.Irp.2013.01.001

Hair, J. F., Tomas, H. G. M., Ringle, C. M., \& Sarstedt, M. (2017). A primer on Partial least squares strucural equation Modeling PLS_SEM. SAGE.

Hernandez-Linares, R., Kellermanns, F. W., Lopez-Fernandez, M. C., \& Sarkar, S. (2019). The effect of socioemotional wealth on the relationship between entrepreneurial orientation and family business performance. BRQ Business Research Quarterly. https://doi.org/10.1016/j.brq.2019.03.002

Hornsby, J. S., Kuratko, D. F., \& Zahra, S. A. (2002). Middle managers' perception of the internal environment for corporate entrepreneurship: assessing a measurement scale. Journal of Business Venturing, 17, 49-63.

Idris, K., and Kabiru, I. G. (2014). Entrepreneurial Training model , a predictor to Entrepreneurs' Success : The Contending viewpoint. Proceeding of Global Finance and Business, (p. 922069).

Inegbedion, D. O. (2019). Empirical Analysis of Entrepreneurial Orientation and Financial Performance in Selected Paint Manufacturing Firms in Lagos State, Nigeria. Global Science Journal, 21(4), 1072-1076.

Jawad, H. (2015). The Effect of Market and Learning Orientations on Organizational Performance of Manufacturing Small and Medium Sized Enterprises in Pakistan. UTM, MALAYSIA.

Kaigama, Y. M. (2018). The Role of Entrepreneurial Competency and Financial Literacy on the Survival of Small Business in Nigeria [utm]. https://doi.org/10.22201/fq.18708404e.2004.3.66178

Karadag, H. (2017). The impact of industry, firmage and education level on financial management performance in small and medium-sized enterprises (SMEs) Evidence fromTurkey. 9(3), 300-314. https://doi.org/doi.org/10.1108/JEEE-09-2016-0037

Kogut, B., \& Zander, U. (1996). What firms do? Coordination, identity, and learning. Organization Science, 7(5), 502-518.

Lee, T., \& Chu, W. (2017). the Relationship Between Entrepreneurial Orientation and. Journal of Family Business Strategy, 8, 213-223. http://www.ajbms.org/articlepdf/3ajbms05-2015-04-05-4206.pdf

Lii, P., \& Kuo, F. (2016). Author's Accepted Manuscript combined competitiveness and firm performance. Intern. Journal of Production Economics. https://doi.org/10.1016/j.ijpe.2016.01.018

Lumpkin, G. T., \& Dess, G. G. (1996). Clarifying the Entrepreneurial Orientation Construct and Linking It to Performance Author ( $s$ ): G . T . Lumpkin and Gregory G . Dess Source : The Academy of Management Review , Vol . 21 , No . 1 ( Jan ., 1996 ), pp . 135-172 Published by : Academy of Man. The Academy of Management Review, 21(1), 135-172. 
Miller, D. (1983). The correlates of entrepreneurship in three types of firms. Management Science, 29(7), 770-791.

Monteiro, A. P., Soares, A. M., \& Rua, O. L. (2019). Linking intangible resources and entrepreneurial orientation to export performance: The mediating effect of dynamic capabilities. Journal of Innovation and Knowledge, 4(3), 179-187. https://doi.org/10.1016/j.jik.2019.04.001

Mueller, S., \& Anderson, A. R. (2014). Understanding the entrepreneurial learning process and its impact on students' personal development: A European perspective. The International Journal of Management Education, Mulgan, 12(3), 500-511. https://doi.org/10.1016/j.ijme.2014.05.003

Prajogo, D. I. (2015). Author' s Accepted Manuscript performance. Intern. Journal of Production Economics. https://doi.org/10.1016/j.ijpe.2015.07.037

Hernandez, R. G. (2018). Two instruments to measure perceptions of the dual model in entrepreneurs and graduates: A Colombian perspective TT - Dois instrumentos para medir as percepçoes do modelo duplo em empresarios e graduados. Uma perspectiva colombiana TT - Deux instruments p. Revista Científica General José María Cordova, 16(22), 39-57. https://doi.org/10.21830/19006586.320

Salome, E., Osita, I., \& Marcel, E. (2012). Entrepreneurial Skills Required By Business Related Graduates for Successful Operation of A Business Enterprise in Enugu Commercial Centre And Enivirons. Arabian Journal of BuSsiness and Mangement Review (OMAN Chapter), 1(10), 6-28.

Shah, N. D., Robert, D., Clinic, M., Steyerberg, E. W., Data, B., Kent, D. M., Analytics, P., \& Analytics, P. (2018). Big Data and Predictive Analytics Recalibrating Expectations. https://doi.org/10.1097/EDE

Trieu, V.-H. (2017). "Getting value from Business Intelligence systems: A review and research agenda." Decision Support Systems, 93, 111-124.

Trott, P. (2010). Innovation Management and New Product Development. (4thEdition (Ed.)). Prentice Hall Financial Times.

Vallabh, D., \& Mhlanga, O. (2015). Influence of demographic factors on business performance in small to medium tourism enterprises ( SMTEs ). African Journal of Hospitality, Tourism and Leisure, 4(2), 1-9. https://www.researchgate.net/publication/309212400

Van der Sluis, J., van Praag, C. M., \& van Witteloostuijn, A. (2007). Why Are the Returns to Education Higher for Entrepreneurs than for Employees? Business, 3058.

Wadho, W., \& Chaudhry, A. (2018). Innovation and fi rm performance in developing countries : The case of Pakistani textile and apparel manufacturers 2$\}$. Research Policy, April, 0-1. https://doi.org/10.1016/j.respol.2018.04.007

Wang, K. Y., Hermens, A., Huang, K.-P., \& Chelliah, J. (2015). Entrepreneurial Orientation and Organizational Learning on SMEs' Innovation. International Journal of Organizational Innovation, 7(4), 71-82. 